\title{
Peran pendidikan karakter dalam penggunaan media sosial bagi remaja
}

\author{
Aizun Riski Safitri ${ }^{1}$, Dian Mego Anggraini ${ }^{2 *}$, St. Helmia Mujahida ${ }^{3}$, Muhyatun Muhyatun ${ }^{4}$ \\ 1,2,3) Institut Agama Islam (IAI) Al-Khairat Pamekasan \\ *) dianmego@alkhairat.ac.id
}

\author{
Article History: \\ Received: 03/08/2021; \\ Revised: 19/10/2021: \\ Accepted: 22/10/2021 \\ Published: 30/10/2021.
}

How to cite: Safitri, A.R., Anggraini, D.M., Mujahida, S.H., \& Muhyatun M. (2021). Peran pendidikan karakter dalam penggunaan media sosial bagi remaja. Orien: Cakrawala Ilmiah Mahasiswa, 1(2), pp. 143-148. DOI: 10.30998/ocim.v1i2.5846

\footnotetext{
(c) (i) This is an open access article distributed under the Creative Commons 4.0 Attribution License, which permits unrestricted use, distribution, and reproduction in any medium, provided the original work is properly cited. (c) 2021, Safitri, Anggraini, Mujahida, \& Muhyatun.
}

\begin{abstract}
Abstrak: pengguna media sosial saat ini didominasi oleh remaja yang kemudian mengalami perubahan ke arah perilaku negatif dan yang tidak sesuai dengan nilainilai luhur bangsa. Remaja saat ini sangat mudah untuk mengakses informasi dengan internet secara bebas dan tidak ada batasan, termasuk dengan berbagi konten-konten yang bersifat amoral. Bahkan demi viral di media sosial remaja rela melakukan apapun termasuk dengan membuat konten negatif dan berbau asusila. Hal ini merupakan efek dari penggunaan media sosial yang berlebihan dan tanpa kontrol baik dari pemerintah dan orang tua serta peran serta masyarakat. Untuk itu pendidikan karakter di sekolah bisa menjadi usaha preventif perubahan perilaku remaja dalam penggunaan media sosial, karena pendidikan karakter berperan penting dalam mengontrol dan meningkatkan kesadaran remaja dalam menggunakan media sosial.
\end{abstract}

Kata Kunci: remaja, pendidikan karakter, sekolah

\begin{abstract}
: social media users are currently dominated by teenagers who then experience a change towards negative behavior and which is not in accordance with the noble values of the nation. Teenagers nowadays are very easy to access information with the internet freely and without restrictions, including by sharing immoral content. Even for the sake of being viral on social media, teenagers are willing to do anything, including by creating negative and socially-smelling content. This is the effect of excessive and uncontrolled use of social media from the government and parents as well as community participation. For this reason, character education in schools can be a preventive effort to change adolescent behavior in the use of social media, because character education plays an important role in controlling and increasing adolescent awareness in using social media.
\end{abstract}

Keywords: youth, character education, school

\section{Pendahuluan}

Salah satu cita-cita besar bangsa Indonesia adalah mencerdaskan kehidupan bangsa. Dari cita-cita besar ini dapat disimpulkan bahwa bangsa Indonesia adalah bangsa yang memiliki pendidikan yang bisa membawa bangsa ini menjadi bangsa yang besar dengan segala potensinya. Dalam mencerdaskan kehidupan bangsa, negara memiliki kewajiban menyelenggarakan pendidikan yang bisa menjadikan masyarakat yang cerdas serta memiliki akhlak luhur sesuai dengan kepribadian bangsa. Pendidikan karakter merupakan aspek yang penting bagi generasi penerus bangsa. Melalui pendidikan karakter setiap individu diberikan bekal intelektual yaitu, setiap individu diberikan pemahaman moral dan spiritual. Kusuma (2004) memaparkan tujuan dari pendidikan karakter ialah untuk membentuk sikap yang dapat 
membawa kita kearah kemajuan tanpa harus bertentangan dengan norma yang berlaku. Pada era globalisasi saat ini, masyarakat Indonesia dapat mengakses berbagai informasi dengan mudah. Perkembangan teknologi menjadi pisau bermata dua yang siap menyerang penggunanya yang tidak siap.

Perkembangan teknologi yang sangat pesat memberikan dampak yang positif dalam dunia pendidikan di Indonesia. Dengan pesatnya perkembangan teknologi para pelaku pendidikan dimudahkan dalam mengakses berbagai ilmu dan pembelajaran yang bisa menunjang pendidikan di Indonesia dalam menciptakan masyarakat yang cerdas serta memiliki nilai luhur. Perkembangan teknologi juga memberikan suatu perubahan tata nilai dan sikap yang menyebabkan adanya pergeseran nilai dan perilaku masyarakat yang irasional menjadi rasional. Di sisi yang berbeda, perkembangan teknologi juga memberikan dampak yang negatif dalam perkembangan pendidikan di Indonesia. Kemudahan dalam mengakses dan menggunakan teknologi menjadikan masyarakat yang individualis.

Dampak negatif lainnya adalah informasi-informasi yang tidak bermoral dapat diakses dengan mudah tanpa ada filter dari pengguna sehingga menjadikan masyarakat yang berbuat kriminal yang tidak sesuai dengan norma dan nilai luhur bangsa. Tilaar (2009) menjelaskan perubahan global yang sedang terjadi, telah merupakan suatu revolusi global (globalisasi) yang melahirkan suatu gaya hidup (a new lifestyle). Perkembangan teknologi yang begitu pesat, memberikan persaingan di antara masyarakat agar bisa mengembangkan diri sendiri mengikuti perubahan yang sangat cepat sehingga memberikan tekanan kepada setiap orang. Persaingan yang muncul membuat setiap orang harus memiliki keterampilan dan kompetensi untuk menunjang kehidupannya di masa yang akan mendatang.

Zahid (2015) menjelaskan bahwa globalization has not only opened informational exchange from developed to developing countries but has also led to the career prospects across the borders. Now, the individuals are expected to develop skills and competencies so that they can attain better job opportunities and consequently they enter into inter-regional competition. Dari pendapat di atas dapat dijelaskan bahwa dalam menghadapi perubahan globalisasi diperlukannya suatu skill dan kompetensi yang berkembang dari masing-masing masyarakat agar membuka kesempatan dalam persaingan dan kompetisi global.

Nasrullah (2015) menyatakan bahwa keberadaan media sosial pada dasarnya merupakan bentuk yang tidak jauh berbeda dengan keberadaan dan cara kerja komputer. Tiga bentuk bersosial, seperti pengenalan, komunikasi, dan kerjasama bisa dianalogikan dengan cara kerja komputer yang juga membentuk sebuah sistem sebagaimana adanya sistem diantara individu dan masyarakat. Media sosial adalah alat komunikasi yang digunakan oleh masyarakat saat ini. Keberadaan media sosial menjadi vital dalam kehidupan karena cara kerjanya yang begitu memudahkan kerja manusia dalam berkomunikasi dan bekerjasama dengan orang lain.

Seiring perkembangan teknologi, media sosial menjadi suatu kebutuhan dasar bagi setiap orang untuk melakukan usaha, belajar, hiburan serta berinteraksi dengan orang lain. Dengan adanya beberapa kemudahan dalam fitur yang ditawarkan membuat media sosial menjadi suatu gaya hidup yang baru bagi masyarakat saat ini. Hal ini seakan-akan menjelaskan bahwa media sosial hadir layaknya dunia baru dimana didalamnya terdapat berbagai macam keberagaman masyarakat yang terhubung melalui dimensi dunia yang tidak nyata.

Dewasa ini, media sosial banyak menimbulkan isu-isu yang menggeser perilaku dan nilai-nilai luhur yang ada di masyarakat. Isu-isu seperti swafoto berlebihan, penipuan-penipuan, tindakan asusila serta rela melakukan apapun agar bisa viral. Isu-isu ini dapat kita lihat sekarang banyaknya pengguna media sosial yang berlomba-lomba memberikan tayangan-tayangan yang 
sifatnya tidak mendidik. Pergeseran perilaku yang tidak sesuai dengan cita-cita bangsa ini akan memberikan dampak yang serius dalam pembangunan bangsa ini.

\section{Metode}

Metode yang digunakan dalam penelitian ini adalah metode library research, menurut Embun metode library research adalah penelitian yang dilakukan hanya didasarkan atas karya tertulis, termasuk hasil penelitian baik yang telah maupun yang belum dipublikasikan (Melfianora, 2017). Sehingga dalam penelitian ini, peneliti melakukan analisis dari berbagai macam sumber yang berkaitan dengan pendidikan karakter dan penggunaan media sosial dikalangan remaja dan menarik suatu analisis yang akurat dan kritis untuk melahirkan sintesa baru, rasional dan logis serta menjadi sebuah kesimpulan yang dapat uji di lapangan. Metode ini mengambil referensi dari beberapa buku, jurnal dan artikel sehingga mempertajam hasil analisis dari peneliti.

\section{Hasil dan Diskusi}

\section{Pendidikan karakter}

Pendidikan karakter menjadi keharusan dalam era globalisasi agar peserta didik tidak mudah terpengaruh oleh perilaku yang tidak baik. Pendidikan karakter berkaitan dengan pengembangan nilai, moral dan kebiasaan yang baik sikap positif untuk membentuk individu yang bertanggung jawab atas tindakan yang dilakukan (Wahyuni, 2016). Saat ini generasi muda yang terpengaruh oleh konten-konten negatif yang menyebabkan rusaknya moral. Akibatnya generasi muda melakukan perbuatan-perbuatan yang menyimpang dari norma agama dan bertentangan dengan nilai luhur bangsa. Oleh karena itu, pendidikan karakter diberikan kepada peserta didik untuk membekali pengetahuan dan kemampuan dalam menyerap informasi yang bertentangan dengan nilai luhur bangsa.

2. Media sosial

Durkheim (dalam Fuchs, 2014) menjelaskan istilah media sosial tersusun dari dua kata, yakni "media" dan "sosial". Media diartikan sebagai alat komunikasi sedangkan kata sosial diartikan sebagai kenyataan sosial bahwa setiap individu melakukan aksi yang memberikan kontribusi kepada masyarakat. Dari pengertian kata di atas, maka dapat disimpulkan bahwa media sosial adalah alat komunikasi yang digunakan untuk proses sosial dalam berkontribusi kepada masyarakat. Namun menurut Nasrullah (2015) menyatakan bahwa untuk menyusun definisi media sosial perlu melihat perkembangan hubungan individu dengan perangkat media. Dengan demikian, dapat dijelaskan bahwa keberadaan media sosial pada dasarnya merupakan bentuk yang tidak jauh berbeda dengan keberadaan dan cara kerja komputer yang membentuk sistem sebagaimana adanya sistem di antara individu dan masyarakat.

Sementara menurut Andreas Kaplan \& Michael Haenlein (2010) media sosial merupakan sebuah kelompok aplikasi berbasis internet yang membangun di atas dasar ideologi dan teknologi Web 2.0, dan yang memungkinkan penciptaan dan pertukaran user-generated content. Media sosial dapat diartikan sebagai sebuah perangkat komunikasi yang memungkinkan untuk saling bertukar konten untuk bertujuan saling memberikan kontribusi. Aktivitas-aktivitas yang sering ditemukan di seluruh penjuru dunia saat ini adalah saling bertukar informasi untuk menunjang dan membantu segala urusan masing-masing pengguna media sosial. Aktivitas ini bahkan bisa terbilang masif dan intensif, sehingga menjadi suatu kebutuhan yang tidak bisa lepas dari masyarakat. Media sosial adalah media online yang mendukung interaksi sosial sehingga 
terjadi suatu dialog interaktif antar pengguna. Kemunculan media sosial yang menyita perhatian dunia terjadi pada tahun 2003. Pada tahun tersebut banyak bermunculan berbagai media sosial dengan berbagai karakter dan kelebihan masing-masing seperti Facebook, Twitter, Google dan lain sebagainya. Saat ini, media sosial menjadi sarana atau aktivitas digital marketing atau bisnis.

3. Media sosial dan isu-isu terkini

Dewasa ini, aktivitas dalam media sosial memberikan suatu gaya hidup baru di tengah masyarakat. Berbagai motif dan tujuan dari pengguna media sosial telah mendasari pergeseran perilaku pada masyarakat umum. Berikut ini, beberapa isu terkini terkait penggunaan media sosial yang menyita perhatian, yaitu swafoto (selfie), cyberwar, belanja daring dan konten creator.

a. Swafoto (selfie)

Swafoto (selfie) merupakan aktivitas yang sering ditemukan pada masyarakat saat ini. Kemajuan teknologi komunikasi dengan fitur kamera yang canggih mempermudah aktivitas swafoto dalam masyarakat. Menurut Nasrullah (2015) kata swafoto (selfie) telah resmi menjadi kata baru yang dicantumkan dalam kamus Oxford English Dictionary pada tahun 2013 yang memiliki pengertian foto diri yang disebarluaskan melalui media sosial. Dari pengertian di atas, dapat disimpulkan bahwa swafoto adalah aktivitas potret diri yang dibuat dengan kamera ponsel cerdas dan disebarluaskan melalui jaringan internet sebagai komunikasi visual. Aplikasi seperti Facebook, Twitter, dan WhatsApp merupakan contoh dari beberapa aplikasi media sosial yang memuat foto diri dan disebarluaskan.

Mengutip dari Nasrullah (2015) sebuah riset yang dilakukan oleh Lembaga Opinium di Inggris terhadap 2005 responden yang berusia antara 18 sampai 24 tahun pada tahun 2013 menunjukkan bahwa dalam sehari, ada lebih dari satu juta foto diri yang dibuat. Realitas sosial ini menunjukkan bahwa kekuatan foto diri adalah artefak kebudayaan yang bisa ditafsirkan dari berbagai sudut pandang. Media sosial merupakan arena untuk menampilkan foto diri tersebut dan pengguna mendapatkan timbal balik dari publikasi tersebut.

b. Cyberwar

Di era digital sekarang ini, teknologi memiliki peran yang sangat penting. Perangkat teknologi komputer dan internet telah menjadi suatu kebutuhan yang tidak bisa dikesampingkan dalam kehidupan sehari-hari. Setiap negara di dunia harus mampu menguasai, mengendalikan dan mengawasi pergerakan setiap orang dalam dunia maya. Teknologi Komputer dan internet menciptakan suatu dunia baru yang dikenal sebagai dunia maya, dimana di dalamnya terdapat warga negara dunia maya yang disebut "netizen", dan melakukan berbagai interaksi dan komunikasi dengan orang lain melalui media sosial.

Cyber warfare memiliki arti perang yang dilakukan di dunia maya (cyberspace) dengan menggunakan teknologi canggih dan jaringan nirkabel/wi-fi. Cyber warfare sendiri berkembang dari cyber crime yang memiliki arti perbuatan melawan hukum atau bentuk kejahatan yang ditimbulkan karena pemanfaatan teknologi internet yang berbasis kecanggihan teknologi komputer dan telekomunikasi. Dalam cyber warfare, terdapat metode penyerangan yang tentunya berbeda dengan perang klasik, perang konvensional atau perang fisik lainnya. Domain dari cyber warfare berada dalam dunia maya, dimana yang menyerang adalah orang yang ahli teknologi informasi yang tidak harus datang langsung ke negara yang diserang. Wilayah yang diserang juga bukan wilayah fisik, wilayah teritorial, atau wilayah geografis, melainkan wilayah dunia maya.

4. Perlunya pendidikan karakter dalam media sosial

Perkembangan teknologi informasi membawa sebuah perubahan dalam masyarakat. Lahirnya media sosial membuat pola perilaku masyarakat mengalami pergeseran baik budaya, etika dan norma yang ada. Media sosial seakan-akan menjadi sarana dalam 
menyampaikan pendapat tertentu serta hujatan yang menyakiti orang lain. Seperti yang kita ketahui bahwa media sosial merupakan sebuah media online, dengan para pengguna bisa dengan mudah berinteraksi dengan dunia virtual dan siapa pun bisa berinteraksi di dalamnya. Penggunaan media sosial menjadi pisau bermata dua yang siap menghancurkan atau membantu pengguna. Media sosial merupakan situs dimana seseorang dapat membuat webpage pribadi dan terhubung dengan setiap orang yang tergabung dalam media sosial yang sama untuk berbagi informasi dan berkomunikasi.

Pengguna dari media sosial yang berasal dari berbagai kalangan dan usia, akan membuat lebih beragam tanggapan serta informasi yang akan didapat bagi pengguna lain. Hal ini akan memberikan perubahan terhadap pola perkembangan sikapnya. Setiap manusia selama hidup pasti akan mengalami perubahan. Perubahan dapat mengenai nilai dan norma sosial, pola-pola perilaku organisasi dan interaksi sosialnya. Perubahan akan semakin cepat seiring dengan perkembangan teknologi komunikasi yang semakin pesat dan menghapus batasan-batasan dalam bersosialisasi. Dalam media sosial tidak ada batasan ruang dan waktu, para pengguna media sosial dapat berkomunikasi kapanpun dan dimanapun.

Dari perubahan yang telah dipaparkan di atas, pentingnya setiap pengguna media sosial memiliki karakter dan nilai luhur bangsa agar bisa lebih cerdas dalam menggunakan media sosial. Peran dari pendidikan karakter dalam menggunakan media sosial sangat dibutuhkan dalam mengontrol dan membatasi setiap pengguna media sosial untuk bersikap dan berperilaku sesuai dengan norma dan nilai luhur serta perbuatan yang tidak melawan hukum. Dalam pendidikan karakter, setiap individu diberikan pemahaman tentang nilai-nilai karakter yang meliputi komponen pengetahuan, kesadaran atau kemauan untuk melaksanakan tindakan atau sikap yang sesuai dengan nilai luhur bangsa. Pendidikan karakter merupakan bagian terpenting dari kehidupan yang tidak pernah ditinggalkan agar bisa menjadi individu yang memiliki nilai luhur.

Berdasarkan pembahasan di atas, dapat disimpulkan bahwa pendidikan karakter memiliki peran dalam menggunakan media sosial. Terlebih para pengguna saat ini yang didominasi oleh kalangan remaja. Pendidikan karakter dinilai penting dalam mengontrol dan membatasi perilaku setiap individu dalam bermedia sosial sehingga dapat menciptakan suatu tatanan sosial yang memiliki nilai luhur bangsa. Pendidikan karakter adalah cara untuk membantu setiap pengguna media sosial membatasi setiap perilaku dan interaksi dengan orang lain di dunia maya. Oleh sebab itu, pentingnya pendidikan karakter untuk ditanamkan oleh setiap pengguna media sosial dalam rangka untuk menekan terjadinya konflik serta tindakan kriminal yang disebabkan oleh media sosial. Dengan kata lain, pendidikan karakter memiliki peran yang sangat penting dalam menggunakan media sosial.

Keterbatasan dari temuan penelitian ini yaitu dalam penelitian ini masih memerlukan kajian mendalam dilapangan dengan temuan-temuan terbaru tidak hanya sebatas pada literaturliteratur buku, artikel dan media sosial, sedangkan untuk implikasi terhadap bimbingan dan konseling yakni guru bimbingan dan konseling dapat mengetahui bahwa pembentukan karakter positif melalui layanan konseling individu, kelompok, bimbingan kelompok dan layanan dalam bentuk lainnya perlu menitikberatkan pada pembentukan karakter siswa di sekolah. Karena dengan memiliki karakter positif peserta didik dapat mengetahui hal-hal pantas dan tidak pantas dalam penggunaan media sosial.

\section{Simpulan}


Pendidikan karakter memiliki peran yang sangat signifikan untuk menjadikan remajaremaja Indonesia sebagai remaja yang memiliki karakter positif sesuai dengan agama dan nilainilai luhur bangsa. Oleh karena itu yang menjadi harapan saat ini dengan memiliki karakter positif tersebut, remaja dalam menggunakan media sosial dapat bijak dalam penggunaanya. Karena hal ini menyangkut pola komunikasi yang berdampak pada pergeseran nilai-nilai sosial seperti perubahan perilaku individu yang tidak sesuai dengan nilai luhur bangsa. Bahkan tidak jarang ditemukan tindakan yang melawan hukum akibat dari tidak mampunya remaja bijak dalam menggunakan media sosial yang disebabkan oleh tidak memiliki karakter positif, pada dasarnya pendidikan karakter merupakan alat untuk mengontrol dalam penggunaan media sosial yang lebih cerdas. Hal ini dikarenakan, pendidikan karakter merupakan suatu sistem penanaman karakter bangsa untuk bisa diaplikasikan dalam kehidupan sehari-hari sehingga tercipta suatu kehidupan yang memiliki martabat.

\section{Ucapan Terima Kasih}

Pada kesempatan ini penulis menyampaikan terima kasih kepada semua pihak yang telah mendukung atas terlaksananya penelitian ini. Secara khusus rasa terima kasih kami sampaikan kepada Bapak Ahmad Andry Budianto, M.Pd., yang senantiasa mendukung dan menstimulasi keinginan untuk meneliti.

\section{Daftar Rujukan}

Andreas M.; Michael Haenlein (2010) Users of the world, united The challenges and opportunities of Social Media. Business Horizons 53(1): 59-68.

Doni Kusuma A. (2007). Pendidikan Karakter. Jakarta: Grasindo.

Irmawati, D. (2011). Pemanfaatane-commerce dalam dunia bisnis. Jurnal Ilmiah Orasi Bisnis, 2, 12-15.

Melfianora. (2017). Penulisan Karya Tulis Ilmiah Dengan Studi Literatur. Studi Literatur, 1-3.

Nasrullah, R. (2015). Media sosial (perspektif komunikasi, budaya, dan sosioteknologi). Jakarta: Simbiosa Rekatama Media.

Sabar Budi Raharjo, Pendidikan Karakter Sebagai Upaya Menciptakan Akhlak Mulia, dalam Jurnal Pendidikan dan Kebudayaan, Vol.16, No.3, Mei 2010, h.232.

Sundawa, Yusti Amelia dan Wulan Trigartanti. Fenomena Content Creator di Era Digital; Volume 4, No. 2, Tahun 2018, ISSN: 2460-6510.

Tilaar, H.A.R. (1998). Beberapa Agenda Reformasi Pendidikan Nasional, dalam Perspektif Abad 21. Jakarta: Penerbit Tera Indonesia.

Undang-undang No. 20 pasal 3 Tahun 2003 Tentang sistem Pendidikan Nasional.

Wahyuni, D. E. (2016). Pengembangan Pendidikan Karakter Bangsa Berbasis Kearifan Lokal dalam Era MEA.

Zahid, Gulnaz. (2015). Globalization, nationalization and rationalization. Procedia - Social and Behavioral Sciences. (174): 109 - 114.

\section{Competing interests:}

The authors declare that they have no significant competing financial, professional or personal interests that might have influenced the performance or presentation of the work described in this manuscript. 